\title{
Tõenäolisus ja motivatsioon ${ }^{1}$
}

\author{
Gérard Genette
}

[1]

17. sajandi Prantsusmaal toimus kaks suurt protsessi tõenäolisuse ${ }^{2}$ [vraisemblance] üle kirjanduses. Neist esimene paigutub puhtalt aristotellikule tragöödia, antud juhul täpsemalt tragikomöödia väljale: selleks on vaidlus [Corneille'] „Cidi” ümber; teise jurisdiktsioon sirutub proosanarratiivi valdkonda: selleks on [Madame de la Fayette'i] „Printsess de Clèves'i” (1678) afäär. Tõepoolest, mõlemal juhul taandub kirjandusteose kriitiline uurimine peamiselt vaidlusele tõenäolisuse üle kummagi loo määravates sammudes: Chimène'i käitumine Rodrigue suhtes pärast krahv don Gormasi surma ning ülestunnistus, mille teeb proua de Clèves oma abikaasa ees. ${ }^{3}$ Mõlemal juhul võib näha ka seda, kuivõrd erinev on tõenäolisus ajaloolisest või eraldisest tõest: „On tõsi,” ütleb Scudéry ${ }^{4}$, „et Chimène naitus Cidiga, kuid pole teps

1 Artikkel „Vraisemblance et motivation” on tõlgitud teosest: Gérard Genette, Figures II. Pariis, Éditions du Seuil 1969, Ik 71-99. Võimalusel on tõlkija asendanud Genette'i originaalviite prantsuskeelsele teosele viitega eestikeelsele tõlkele. Artikli esitusviis vastab tõlkeraamatu originaalile, siinse ajakirja jaoks on kohandatud üksikuid vormindusnõudeid - toim M. L.

2 Mõistel puudub üksühene eestikeelne vaste. Kohakuti satuvad tähendusväljad, mida eesti keeles katavad sõnad tõenäosus ja tõepärasus. Prantsuskeelne vraisemblable (sõna-sõnalt: tõe sarnane) on tavakasutuses väljendanud nii võimalikkust (17. sajandi kontekstis) kui ka usutavust, kehtivat sarnasust (hiljem, 19. sajandist tänapäevani). Samu tähendusi väljendab osadeks võetuna eestikeelne tõenäoline. Vrd: „IIm on seda nägu, et kisub vihmale” (võimalikkus); „Peeter on tuntud poliitiku nägu” (kehtiv sarnasus). Nii on lähteteksti vraisemblable tõlgitud tõenäoliseks; vraisemblance aga tavakasutuses olevast tõenäosusest pisut irduvalt, sarnasust rõhutavalt tõenäolisuseks (vrd: ühenäolisus, inimnäolisus jne). Üksiti eelistatakse essee keskse mõiste vraisemblable tõlkevastena eesti keeles tõenäolist taotlusega rõhutada mõiste ajadimensiooni kui Genette'i jaoks olulist tagasivaatelisust antud otsuse juures: mitte „a vastab (ei vasta) kujutlusele tõesest, on (ei ole) tõepärane (usutav)”, vaid „a vastas (ei vastanud) ettekujutusele tõesest, oli (ei olnud) tõenäoline”. Tõlge lähtub artikli rõhuasetusest, mis tundub olevat pigem geneesil kui retseptsioonil, ning intuitsioonist, et representatsiooni tõ e pärast olulisem näib autorile käesolevas artiklis olevat realisatsiooni tõ enäosus. (Tõlkija märkus.)

3 Me ei lasku siin nende kahe afääri üksikasjadesse. Neist esimese kohta leiab lähema käsitluse A. Gasté raamatust „La querelle du Cid” („Vaidlus Cidi ümber”; Pariis, 1898), teise kohta ajakirja Mercure Galant 1678. aastakäigust, Valincouri teosest „Lettres sur le sujet de la Princesse de Clèves” („Kirjad „Printsess de Clèves'i” asjus”; 1678, välja andnud A. Cazes 1925) ning kogumikust „Conversations sur la critique de la Princesse de Clèves” („Vestlusi „Printsess de Clèves'i” kriitika kohta”; Pariis, 1679). Üks Fontenelle'i kiri Mercure'ist ja üks teine, Bussy-Rabutini oma proua de Sévignéle, leiduvad lisadena romaani väljaandes „Cazes, Les Belles Lettres” (1934). Klassikalisi teooriaid vraisemblance'i kohta vt teostest: René Bray „Formation de la Doctrine classique”, Pariis, 1927; Jacques Schérer „La Dramaturgie classique en France”, Pariis, 1962.

4 Georges de Scudéry (1601-1667) - prantsuse proosa- ja draamakirjanik. (Tõlkija märkus.) 
mitte tõenäoline, et autundega tütar naituks oma isa mõrtsukaga" ${ }^{5}$; ning Bussy-Rabutin ${ }^{6}$ : „Proua de Clèves'i ülestunnistus abikaasale on ekstravagantne ning seda saaks teha üksnes tõsiloos; kui aga lugu mõeldakse välja, on kangelanna varustamine niivõrd ebaharilike tunnetega [sentiment] naeruväärne." Lisaks sellele on mõlemas näites kõige puhtamal kujul täheldatav see lähedane kokkupuude, õigemini sulam, milles on mõisted tõenäolisus ja sündsus; sulam, mida esindab suurepäraselt tuntud (kohustuse ja tõenäosuse) kahemõttelisus tegusõnas „pidama”: „Cidi” süžee [sujet] on halb, kuna Chimène e i pidanuks Rodriguet'i pärast surmaga Iõppenud duelli vastu võtma, soovima tema võitu don Sancho üle, nõustuma, ka mitte vaikimisi, abieluväljavaadetega jne. „Printsess de Clèves'i” tegevustik on halb, kuna proua de Clèves ei pidanuks oma abikaasat usaldusaluseks võtma - mis tähendab ühtaegu mõistagi seda, et need teod on vastuolus heade kommetega ${ }^{7}$ ning käivad vastu ka mis tahes mõistuspärastele ootustele: seaduserikkumine ja kõrvalekalle. Niisamuti kirjutab abbé d'Aubignac $^{8}$, jättes lavalt kõrvale sellise ajaloolise sündmuse nagu Agrippina tapmine Nero poolt: „See barbaarsus poleks mitte üksnes jube nende jaoks, kes seda näeksid, vaid koguni uskumatu, sest see ei pidanuks juhtuma," või siis teoreetilisemas võtmes: „Lava ei näita asju mitte sedasi, nagu need olid, vaid sedasi, nagu need pidanuks ole ma." ${ }^{9}$ Aristotelesest saadik on teada, et draama - ja laiemalt kogu kirjanduse - aines [sujet] on mitte tõene ega võimalik, vaid tõenäoline, kuid üha selgemini [nettement] kaldutakse seda tõenäolisust samastama olema-pidavaga [devant-être]. Seda samasust ja vastandlikkust tõenäolisuse ja tõe vahel väljendab ühe hingetõmbega ja tüüpiliselt platoonilistes terminites Père Rapin ${ }^{10}$ : „Tõde teeb asjad vaid selliseks, nagu nad on, ning tõenäolisus teeb nad selliseks, nagu nad peaksid olema. Et tõde koosneb ainuliste tingimuste segust, on see peaaegu alati puudulik. Maailma ei sünni midagi, mis ei kaugeneks oma idee täiusest, millest ta sünnib. Algupärandeid

5 „Observations sur le Cid” („Tähelepanekud Cidi kohta”), rmt-s „Gasté”, 1898, Ik 75.

6 Roger de Bussy-Rabutin (1618-1693) - prantsuse memuarist. (Tõlkija märkus). Tsitaat teosest „La Princesse de Clèves". Cazes, 1934, Ik 198.

7 Sel kujul, nagu neid toona nähti. Jättes kõrvale maotu vaidluse, pöörakem tähelepanu vaid mõlema kriitika märkimisväärselt aristokraatlikule üldiseloomule: „Cidi” kohta käivas on isiklikest tunnetest ettepoole seatud veritasuvaim ja perekondlik pieteet, „Printsess de Clèves'i” kohta käivas aga abielusideme venitamine [distension] ja abikaasade vaheline põlgus igasuguse tundmusliku läheduse vastu. Bernard Pingaud („Madame de la Fayette par elle-même"; Pariis, Seuil, 1959, Ik 145) võtab pihtimuse suhtes vaenulike lugejate enamiku hinnangu hästi kokku: „Proua de Clèves'i käitumine näib neile viimse piirini buržuaalik.”

8 Abbé d’Aubignac, François Hédelin (1604-1676) - prantsuse dramaturg ja teoreetik. (Tõlkija märkus.)

9 "La Pratique du Théâtre” (1657). Alžiir, Martino 1927, Ik 76 ja 68.

10 René (Père) Rapin (1621-1687) - prantsuse poeet, teoloog ja ajaloolane. (Tõlkija märkus.) Tsiteeritud teosest „Réflexions sur la Poétique” (1674), CEuvres II. Amsterdam, 1709, Ik 115-116. 
ja eeskujusid tuleb otsida tõenäolisusest ja asjade universaalsetest printsiipidest - kuhu miski aineline ega ainuline nende puhtust rikkuma ei pääse." Nii läheb sisemine sündsus segamini vastavuse, sobivuse või kombepuhtusega, mida nõuab Aristoteles ja mis on ilmselgelt tõenäolisuse algeiks: „,"Kombepuhtuse all,” ütleb Mesnardière ${ }^{11}$, „peab poeet mõistma seda, et ilma tingimatu tarviduseta ei tuleks tal [oma loomingusse] kunagi sisse tuua vaprat tütarlast, õpetatud naist ega arukat teenrit... Nende kolme tegelaskuju lavale toomine sääraste üllaste omadustega varustatuna tähendaks otsest lööki harjumusliku tõenäolisuse pihta..., et ta ei tohiks kunagi (välja arvatud hädavajadusel) tulla lagedale sõjaka asiaadi, ustava aafriklase, jumalakartmatu pärslase, aumehest kreeklase, suuremeelse traaklase, terase sakslase, tagasihoidliku hispaanlase ega ebaviisaka prantslasega. ${ }^{12}$ "Õigupoolest langevad tõenäolisus ja sündsus ühe kriteeriumi alla, milleks on „kõik see, mis vastab avalikule arvamusele"."13 See arvamus, olgu tegelik või oletuslik, on üsna täpselt see, mida tänapäeval nimetataks ideoloogiaks, teisisõnu kogum juhtmõtteid ja eelarvamusi, millest moodustub ühtaegu maailmavaade ja väärtushinnangute süsteem. Seega võib e batõ e nä o lisuse hinnangut väljendada niisama hästi ka eetilisel kujul, näiteks: „,"Cid” on halb näidend, kuna esitab näidislikuna nurjatu tütre käitumist,” ${ }^{14}$ või loogilisel kujul, näiteks: „,"Cid” on halb näidend, kuna paneb korraliku tüdrukuna esitletud kangelanna laiduväärselt käituma." ${ }^{15}$ Kuid on kaunis selge, et neid kahte hinnangut hoiab ülal üks ja sama juhtmõte, nimelt, et „tüdruk ei peaks naituma oma isa mõrtsukaga”, või siis, et „korralik tüdruk ei naitu oma isa mõrtsukaga”, või tagasihoidlikumalt, et „korralik tüdruk ei peaks naituma”, jne; teisisõnu on säärane tegu äärmisel juhul võimalik ja mõeldav, ent sel juhul kõrvalekaldena. Igatahes peaks draama (ja ilukirjandus üldiselt) esindama üksnes olemuslikku. Chimène'i kõlvatus ja proua de Clèves'i jultumus on - Bussy-Rabutini ilmekat väljendust kasutades - „ekstravagantsed” ja ekstravagantsus on tegeliku eesõigus.

Jämedates joontes selline on vaimne hoiak, millele eksplitsiitselt tugineb klassikaline tõenäolisuse teooria, implitsiitselt aga kõik tõenäolisuse süsteemid, mis on jätkuvalt jõus populaarkirjanduse žanrites, nagu kriminaalromaan, lemberomaan, vestern jne. Ajajärgust ajajärku ja žanrist žanrisse võib selle süsteemi sisu - seda moodustavate normide või tu um -

11 Mesnardière (1610-1663) - prantsuse füüsik, kirjamees ja dramaturg. (Tõlkija märkus.)

12 Tsiteeritud teost „La Poétique” (1639), rmt-st: Bray, op. cit., Ik 221.

13 Rapin, op. cit., Ik 114. Selline on tema tõenäolisuse määratlus.

14 Scudéry (Gasté 1898, Ik 79-80): „Cidi” lahendus „haavab häid kombeid”, näidend tervikuna „on väga halvaks näiteks".

15 Chapelain (ibid., Ik 365): „,„Cidi” narratiiv on puudulik oma kõige olulisemas osas [---], kuna [---] poeet ei hoia selle vooruslikuna tutvustatud tüdruku kommete sündsust." 
sete otsuste [jugements d'essence] hulk - tervenisti või osaliselt muutuda (nii näiteks märgib d'Aubignac, et tõenäolisus kreeklaste poliitikas, kes olid vabariiklased ja omaks võtnud „usu”, et „monarhia on alati türanlik”, pole 17. sajandi prantsuse publiku jaoks enam vastuvõetav: "Me ei taha sugugi uskuda, et kuningad võiksid olla nurjatud." ${ }^{16}$ Selleks, mis jääb alles ja mis tõenäolise defineerib, on normi austamise formaalne põhimõte, teisisõnu: kehtiv kaasavussuhe [rapport d'implication] ühele või teisele tegelasele omistatud partikulaarse käitumise ning implitsiitse ja püsistunud üldise juhtmõtte ${ }^{17}$ vahel. See kaasavussuhe toimib ka seletusprintsiibina: üldine määrab kindlaks ja seega seletab partikulaarset, nii et (näiteks) mingi tegelase käitumine on mõistetav, kui see suudetakse kirjutada mingi omaks võetud juhtmõtte arvele, misjuures seda tagasiviidet käsitletakse liikumisena tagajärjelt põhjusele: Rodrigue kutsub krahvi duellile sellepärast, et "miski ei või takistada heast perekonnast poissi oma isa au riivamise eest kätte maksmast". Ja ümberpöördult: kellegi käitumine on mõistetamatu või ekstravagantne, kui mitte ükski omaks võetud juhtmõte sellest aru anda ei või. Mõistmaks proua de Clèves'i pihtimust, tuleks see siduda mingi säärase juhtmõttega nagu „korralik abielunaine peab oma mehele usaldama kõik hingeasjad”; 17. sajandi Prantsusmaal seda juhtmõtet ei tunnistata (võib niisama hästi öelda, et seda pole olemas); sellele eelistataks meelsasti seda, mille pakub ajalehes Mercure Galant keegi šokeeritud lugeja: „Korralik abielunaine ei peaks ealeski oma mehe meelerahu mängu panema." Seega on printsessi käitumine mõistetamatu nimelt sel põhjusel, et kujutab enesest tegu ilma juhtmõtteta. Madame de la Fayette on muide teadupärast esimene, kes selle anomaalia skandaalsevõitu kuulsust oma kangelanna suu kaudu rõhutab: „, [---] ma tunnistan teile üles asja, mida iial oma mehele pole tunnistatud,” või teisal: „Niisuguse ülestunnistuse erakordsus, mille taolist ta [proua de Clèves] teist ei teadnud," või siis jällegi: „Maailmas ei ole teist samasugust lugu," ja koguni (siin tuleb arvesse võtta ka olukorda, mis sunnib teda proua troonipärija ees teesklema, kuid need sõnad väärivad välja toomist): „See lugu ei näi mulle eriti tõenäoline." ${ }^{18}$ Selline originaalsuste paraad on juba iseenesest klassikalisele vaimule väljakutseks. Ent tuleb sellegipoolest lisada, et Madame de la Fayette oli end kindlustanud mõnevõrra teistviisi, paigutades oma kangelanna olukorda, millest peale säärase pihtimuse ühtki väljapääsu ei olnud, ning andes nõnda vajalikkuse (kreekalikus, Aristotelese anankaion'i - paratamatuse - tähenduses) abil õigustuse sellele, millel seda tõ enäolisuse poolest ei olnud: kui prints de Clèves tahab panna abikaasat õukonda tagasi tulema, leiab

16 „Pratique du Théâtre”, Ik 72-73.

17 Aristotelese jaoks, nagu teada, väljendab juhtmõte (maksiim) midagi üldist inimolendite käitumises (Retoorika II, 1394a-95b) - seal aga on tegu kõnemehe juhtmõtetega. Tõenäolise juhtmõtted võivad oma üldisuse astmelt tugevasti kõikuda, kuna on ju näiteks teada, et komöödia tõenäoline pole sama, mis tragöödia või eepose oma.

18 „Printsess de Clèves“ (tlk Esta Rand, Fantaasia, 2004), Ik 88, 91, 98, 101. (Tõlkija märkus.) 
proua de Clèves end olevat sunnitud mehele oma äraoleku põhjuse paljastama, nagu ta muide juba ette oli aimanud: „[---] ja kui härra de Clèves püüab kangekaelset seda takistada või tahab selle põhjust teada, võib juhtuda, et teen talle ja samuti iseendale seda kurja, et ütlengi talle." Kuid on vägagi selge, et sedalaadi motivatsioon pole autori silmis otsustav, kuivõrd toodud fraasi lükkab tagasi järgmine: „Ta küsis endalt, miks oli ta midagi nii riskantset teinud, ja avastas, et oli sellesse ettevõtmisse sööstnud peaaegu ette kavatsemata."19 Tõepoolest, sunnitud kavatsus ei ole päriselt kavatsus; õige vastus küsimusele „miks?” on: "sellepärast, et ta ei oleks teisiti saanud teha," kuid see vajalikkuse „sellepärast, et” ei oma just kõrget psühholoogilist väärtust ja vaidlustes ülestunnistuse üle ei paista seda kuigivõrd arvesse võetavat: klassikalise moraali järgi on ainsad väärikad põhjused tõenäolisuse omad.

Tõenäoline narratiiv [récit vraisemblable] on niisiis narratiiv, milles tegevused - justkui üksühene hulk rakendusi või erijuhtumeid - vastavad adresseeritava publiku poolt tõestena vastu võetavate juhtmõtete kogumile. Need juhtmõtted aga jäävad - nende omaksvõetuse tõsiasja enese tõttu - enamasti implitsiitseks. Suhe tõenäolise narratiivi ja tõenäolisuse süsteemi vahel, millele narratiiv end kohandab [s'astreint], on seega olemuslikult tumm: žanrikokkulepped töötavad loomulike jõudude ja sunduste süsteemina, millele süžee allub neid justkui tajumata ning, a fortiori, neid nimetamata. Näiteks klassikalises vesternis rakendatakse (muu hulgas) kõige rangemaid käitumisreegleid, ilma et neid kunagi selgitataks, sest vaikivas kokkuleppes teose ja selle lugejaskonna vahel on need täiesti enesestmõistetavad. Tõenäoline on seega antud juhul tähistatav ilma tähistajata või õigemini ei leidu muud tähistajat peale teose enese. Siit ka see tõenäoliste teoste vägagi tajutav võlu, mis hüvitab sageli kuhjaga nende ideelise vaesuse ja lameduse: suhteline vaikus nende tööpõhimõtetes.

Ahela teises otsas - implitsiitse tõenäolisuse seisundi vastandäärmuses - võiksid leiduda igasugusest avaliku arvamuse truudusest kõige jäägitumalt vabanenud teosed. Siin narratiiv üldiste tõdede süsteemist kinni pidamise üle enam ei muretse, vaid sõltub üksnes mõnest partikulaarsest tõest või sügavast kujutelmast. Radikaalne algupärasus, säärase käigu sõltumatus, asetab ta ideeliselt otse tõenäolise-orjuse [vraisemblable] vastandpoolusele, ent neil kahel hoiakul leidub üks ühisjoon, milleks on kommentaaride ja õigustuste väljajäetus [effacement]. Teise hoiaku näideteks viidakem vaid kõrgile vaikusele, millega ümbritseb end Julieni katse mõrvata proua de Rênal „Punases ja mustas” või Vanina abiellumine prints Savelliga „Vanina Vanini” Iõpus: need järsud sammud pole iseenesest „mõistetamatumad” kui mõnedki muud ja saamatuimalgi realistlikul autoril polnuks nende õigustamisega nii-öelda mugava psühholoogia võtete abil suuremat vaeva. Näib aga, et Stendhal 
otsustas need meelega alles jätta või ehk anda neile oma mis tahes selgitustest keeldumise kaudu see metsik isikupära, mis suured teod - ja suured teosed - ennustamatuks teeb. Tõevarjund, kaugel igasugusest realismist, on siin lahutamatu ägedast omaks võetud meelevaldsuse tundest - täieliku meelevaldsuse, mis end õigustama ei vaevugi. Midagi sellesarnast võib olla ka mõistatuslikus „Printsess de Clèves'is”, millele Bussy-Rabutin heitis ette, et teos „on mõelnud rohkem sellele, kuidas eristuda ülejäänud romaanidest, kui sellele, kuidas jääda kooskõlla tavamõistusega". Igatahes võib temas märgata seda meelevaldsust, mis peab ühtaegu tähtsaks oma „klassikalist“ osist (ehk lugupidamist tõenäolisest) ja „modernistlikku“ osist (ehk põlgust tõenäolisuste suhtes): äärmine kokkuhoidlikkus kommentaaride arvelt ja üldiste juhtmõtete peaaegu täielik puudumine ${ }^{20}$, mis võib mõjuda üllatavana narratiivis, mille Iõppredaktsiooni on teinekord omistatud La Rochefoucauld'le ning mis käib ometigi moralistliku romaani ette. Tegelikult pole sellele stiilile midagi võõramat kui õpetlik epifraas ${ }^{21}$ - justkui oleksid selles aset leidvad teod alati kas all- või ülalpool mis tahes kommentaari. Ehk võlgneb „Printsess de Clèves” oma väärtuse puhta narratiivi musternäidisena nimelt sellele paradoksaalsele seisukorrale.

\section{[2]}

See, kuidas need kaks „äärmust“, mida siin esindavad kõige alandlikumat laadi tõenäoline narratiiv ja kõige vabamat laadi ebatõenäoline narratiiv, ühinevad tummuses, kui asi puudutab tegevuse ajendeid ja juhtmõtteid - siin liiga ilmselgeid, seal jälle liiga hämaraid, et neid seletama hakata -, paneb loomulikult oletama pascallikku "astmestikku“ narratiivide skaalal, mille esimesel, loomuliku ignorantsi astmel paikneb tõenäoline narratiiv, ja kolmandal, eneseteadliku õpitud ignorantsi astmel mõistatuslik narratiiv. Niisiis jääb üle leida poolriukaliku narratiivi tüüp, mis paigutuks vahepealsele astmele, teisisõnu: ulatuks välja tõenäolise loomulikust vaikusest, kuid poleks veel saavutanud selle sügavat vaikust, mida nimetaksime meelsasti - laenates Yves Bonnefoylt ühe ta raamatu pealkirja ebatõ e nä olis eks [l'improbable]. Riisudes sellelt astmestikult - niivõrd, kui see on võimalik - igasugused hinnangulised kaastähendused, võiks vahepealsuse piirkonda paigutada narratiivi tüübi, mis on liiga kaugel tõenäolisuse trafarettidest, et tugineda tavaarvamusele, samas aga selle arvamusega liigagi nõus, et suruda talle kommentaarideta peale tegusid, mille põhjused võiksid talle kättesaamatuks jääda: narratiiv, mis on liiga algupärane (ehk ka liiga

20 Bernard Pingaud (op.cit., Ik 139) väidab vastupidist, mis on veidi üllatav, isegi kui võtta arvesse neid tegelastele omistatud harvu juhtmõtteid, mida siin arutluse alla ei võeta (ainsa erandiga, mis tuleb seda enam esile: rida Nemours'i juhtmõtteid balli kohta (La Fayette, Ik 24).

21 See mõiste kaldub siin kõrvale oma rangest retoorilisest tähendusest (ootamatu laiendus näiliselt lõpetatud lausele), märkimaks diskursuse igasugust sekkumist narratiivi - umbkaudu seda, mida retoorikas nimetataks sõnaga epifoneem, mis on meile muudel põhjustel tülikaks muutunud. 
tõ e ne), et jääda lugejale läbipaistvaks, ent alles ${ }^{22}$ liiga arglik või liiga lipitsev, et oma opaaksus enda peale võtta. Nii peaks säärane narratiiv püüdma hankida endale vajaka jäävat läbipaistvust, rohkendades seletusi, varustades kõik kavatsused lugejale teadmatute juhtmõtetega, mis oleksid võimelised tegelaste käitumise ja intriigide järgnevuse kohta aru andma, ühesõnaga, mõeldes enda jaoks välja omaenese trafaretid ning teeseldes igas töös oma ürituse huvides kunstlikku tõenäolisust, mis oleks teooria - sedakorda häda sunnil eksplitsiitne ja avalik - omaenese praktika kohta. Seda tüüpi narratiiv ei ole puhtalt hüpoteetiline, oleme kõik sellega tuttavad ja oma mandunud vormides ummistab see kirjandust oma Iõppematu lobaga jätkuvalt. Parem vaadelda seda siin tema kuulsusrikkaimast, üksiti küllap ka iseloomulikemast ja enim süüdistatud küljest: mõistagi tuleb juttu balzaclikust narratiivist. Sageli on pilgatud (ja sageli jäljendatud) neid pedagoogilisi klausleid, mis „Inimliku komöödia” selgitavaid tagasivaateid jõulise rohmakusega sisse juhatavad: „Ja nimelt sellepärast...”; „Järgneva mõistmiseks on ehk tarvilikud mõned selgitused...”; „See asjaolu nõuab selgitamist...”; „Siia on tarvilik lisada mõned selgitused...”; „Selle loo mõistmiseks...” jne. Kuid Balzaci selgitused ei puuduta mitte üksnes - ega isegi mitte peamiselt - asjaolude omavahelist haakumist; kõige sagedamini ja kõige iseloomulikumal kujul ilmneb see partikulaarse asjaolu õigustusena mõne lugejale tundmatuks või ehk unustatuks peetava üldise seaduse kaudu, mida jutustaja peab talle teatavaks tegema või meelde tuletama. Siit nood tuntud “konksud”: „Nagu kõik vanapiigad...”; „Kui üks kurtisaan...”; „Üksnes hertsoginna...”. Näiteks annab provintsielu, mis oletatakse hargnevat Pariisi lugejaskonna jaoks eksootilises „rahvakultuuris”, alust ammendamatuks didaktiliseks eestkosteks: „Härra Grandet'l oli Saumuris eriline reputatsioon, mille põhjust ja mõju ei suuda mõista inimesed, kes pole lühemat või pikemat aega provintsis elanud...” („Eugénie Grandet” ${ }^{23}$ ); „See sügav kuristik võib tunduda arusaamatuna neile, kes pole märganud kommete erinevust linnades, mis jagunevad üla- ja all-linnaks..." („Kaotatud illusioonid” ${ }^{24}$ ); „Ainult teie, vaesed provintsi heloodid, kes te peate ületama pikemaid seisuste vahemaid kui pariislased, kelle silmis need vahemaad järjest vähenevad, [---] ainult teie mõistate...” („Kaotatud illusioonid” ${ }^{25}$ ). Sellest raskusest puretud, nagu Balzac oli, ei koonerdanud ta ainsagi võimalusega selleks, et luua ja selleks et kehtes-

\footnotetext{
22 Seda sõna ei tohiks mõista tema ajalises tähenduses. Kui siin saab kõnelda mingist ajaloolisest arengust, siis ranges mõttes kindlasti mitte.

23 Honoré de Balzac, Inimlik komöödia. Valitud teosed IV (edaspidi: IK IV). TIk N. Toiger Tallinn: Eesti Riiklik Kirjastus, 1957, Ik 10. (Tõlkija märkus.)

24 IK IV, IK 36.

25 Honoré de Balzac, Inimlik komöödia. Valitud teosed VI (edaspidi: IK VI). TIk I. Pau. Tallinn: Eesti Riiklik Kirjastus, 1958, Ik 54. (Tõlkija märkus.)
} 
tada - ning on ju teada, kui hästi see tal õnnestus - provintslik tõenäolisus, mis kujutab enesest tõeliselt antropoloogilist vaadet prantsuse maaelule oma sotsiaalsetele struktuuridega (nagu äsja nägime), oma tegelaskujudega (provintsi ihnuskoi Grandet vastanduvalt Pariisi innuskoile Gobseckile), oma ametitüüpidega (vt provintsi asjaajaja-advokaat „Kaotatud illusioonides"), oma kommetega (,...provintsielu kitsus” ${ }^{26} ; \ldots$...provintsi ausad ja ranged kombed”27; „Du Croisier' abiellumine ei süüdanud mitte ainult halastamatu sõja, nagu seda osatakse pidada provintsis..." $\left.{ }^{28}\right)$, oma intellektuaalsete joontega (,...andudes provintslastele omasele analüüsimismaaniale $29 " ;$,...nagu provintsielanikud tavaliselt kõike kaaluvad” ${ }^{30} ; \ldots .$. nagu oskavad varjata vaid provintsielanikud..."31) ja oma kirgedega ( „...tugev ja tumm vihavaen, nagu seda leidub vaid provintsis"32) - nii palju vormeleid, mis ühes hulga teistega moodustavad „mõistmiseks tarviliku” 33 ideoloogilise background'i suurele osale „Inimlikust komöödiast”. Balzacil on teadupärast „kõige kohta [oma] teooriad” ${ }^{34}$, kuid need teooriad pole pelgalt teoretiseerimise rõõmuks, vaid teenivad eeskätt narratiivi: on sellele iga hetk tagatiseks, õigustuseks ja captatio benevolentiae'ks ${ }^{35}$, täidavad selle pragusid ja tähistavad kõik selle ristteed.

Sest Balzaci narratiiv jääb sageli üsna kaugele sellest vääramatust jutujärjest, milleks teda peetakse usust tema enesekindlusse ja sellesse, mida Maurice Bardèche nimetab tema „väliseks ranguseks”. Sama kriitik tõstab juba üksnes „Tours'i kürees” esile „kanoonik Troubert'i vägevust, preili Gamard'i pleuriiti ja vastutulelikkust, mis laostab peavikaari, kui tema mantlit kõige enam vajatakse, „kui „kokkulangevusi, mis on pisut liiga arvukad, et märkamatuks jääda". ${ }^{36}$ Ent need pole vaid juhuslikud vastutulelikkuse ilmingud, mis paljas-

26 Honoré de Balzac, Inimlik komöödia. Valitud teosed V. (edaspidi: IK V). TIk A. Kurfeldt. Tallinn: Eesti Riiklik Kirjastus, 1957, Ik 18. (Tõlkija märkus.)

27 IK V, Ik 106.

28 IK IV, IK 209

29 IK IV, IK 50.

30 IK IV, IK 270

31 IK IV, IK 290

32 IK IV, IK 199.

33 IK VI, IK 79.

34 Claude Roy, Le Commerce des classiques. Paris, Gallimard, 1959, Ik 191.

35 (Lugeja) heasoovlikkuse taotluseks (lad k). (Tõlkija märkus.)

36 Maurice Bardèche (1907-1998) - prantsuse esseist, kunsti- ja kirjanduskriitik (tõlkija märkus). Siin tsiteeritav teos: „Balzac romancier", Pariis, Plon, 1947, Ik 253. 
tavad veidigi umbusklikumale lugejale igas narratiivipöörakus selle, mida Valéry oleks nimetanud „Balzaci käeks”. Vähem ilmsed, kuid arvukamad ja lõppeks tähtsamad on sõnavõtud, mis puudutavad otsuseid individuaalse ja kollektiivse käitumise kohta ja ilmutavad autori tahet tegevust iga hinna eest sellesse ja mitte teise suunda juhtida. Puhta põhitegevuse pikad lõigud - olgu intriig kõrgseltskondlik nagu Rubempré „hukkamine” „Kaotatud illusioonide" teises osas või juriidiline nagu Séchard'i oma kolmandas osas - on täis neid otsustavaid tegusid, mille tagajärjed võinuksid olla ka hoopis teistsugused, neid „saatuslikke vigu”, mis võinuksid otsustada võidu, ja neid „väljapeetud kavalusi”, mis võinuksid pöörduda katastroofiks. On mõni Balzaci tegelane eduteel, tasuvad kõik ta teod end ära; on ta aga allakäiguteel, töötavad kõik ta teod - isegi samad, mis teda edasi viisid - tema vastu: ${ }^{37}$ inimaskelduste ebakindluse ja ümberpööratavuse kohta kaunimat näidet ei leidu. Kuid seda määramatust, millest Balzac häbenemata kasu Iõikab, ei soostu ta ise tunnistama, veel vähem aga paljastama, kuidas ta ise sündmuste käiku manipuleerib: ja nimelt siin astuvad mängu teoreetilised õigustused. „Eugénie Grandet's” tõdeb ta ise: „Küllalt sageli näivad teatavad inimelu toimingud kirjanduslikus väljenduses ebatõenäolistena, ehkki nad on õiged. Ent kas mitte sellepärast, et peaaegu alati jäetakse meie spontaansed otsused psühholoogiliselt valgustamata ega seletata neid saladuslikult tekkinud põhjusi, mis nad vajalikuks tegid? [---] Paljud inimesed eelistavad eitada sündmuste arenemist, et mitte hakata mõõtma sidemete, sõlmede ja ahelate jõudu, mis moraalivallas salaja seovad üht tegu teisega." ${ }^{38}$

Võib tõesti märgata, et „psühholoogilise valgustuse” ülesandeks on siin ebatõenäoli sused minema nõiduda, avaldades - või eeldades - sidemeid, sõlmi ja ahelaid, mis Balzaci poolt „moraalivallaks” nimetatus sidusust [cohérence] enamal või vähemal määral kindlustavad. Siit ka need balzaclikule diskursusele iseloomulikud entümeemid, mis teadjatele rõõmu valmistavad ja millest osa ei varjagi oma funktsiooni täitematerjalina. Miks muidu ei suuda preili Cormon ära arvata Athanase Gransoni tundeid? „Suuteline leiutama kõiksugu tundepeenusi, mis talle algusest saadik hukatuslikeks kujunesid, ei märganud ta neid Athanase'i juures. See psühholoogiline nähtus ei tundu ebatavaline neile, kes teavad, et südame omadused on niisama sõltumatud vaimu omadustest nagu geeniuse võimed hinge üllusest. Täiuslikud inimesed on nii haruldased, et Sokrates..." („Vanapiiga”39). Miks pole Birotteau pärast Chapeloud' pärandi endale saamist oma eluga täielikult rahul?

37 „Auahnete ja kõikide nende elus, kes ei suuda saavutada edu teisiti kui ainult inimeste ja olukordade abil ning enam-vähem hästi läbi mõeldud tegevusplaani kohaselt, mille järgi toimitakse ja millest täpselt kinni peetakse, saabub kohutav silmapilk, kus mingi tundmatu jõud mõistab nad karmidele katsumustele: mitte millegagi pole enam õnne, kõik niidid katkevad või lähevad sassi, igalt poolt sajavad kaela õnnetused.” („Kaotatud illusioonid” IK VI, Ik 468.) Balzaci puhul on selle tundmatu jõu nimeks sageli Balzac ise.

38 IK IV, Ik 85-86. (Artikli autori esiletõsted.)

39 IK V, Ik 132-133. (Artikli autori esiletõsted.) 
„Võrratu heaolu, mida ihaldavad kõik olendid ja millest ta oli nii kaua unistanud, sai talle osaks. Aga et kõigil inimestel, is egi preestril, on raske elada ilma mõne lemmikideeta, siis oli abbé Birotteau juba pooleteise aasta eest asendanud oma kaks rahuldatud iha uue sooviga - saada kanoonikuks.” ("Tours'i küree”40). Miks hülgab seesama abbé Birotteau preili Gamard'i salongi (millest kogu draama teadupärast alguse saab)? „Vikaari deserteerimise põhjust on kerge mõista. ${ }^{41} \mathrm{Kuigi}$ ta kuulus nende hulka, kelle päralt peab tõotuse kohaselt ühel päeval olema taevariik: õndsad on vaimust vaesed! - ei võinud ta, nagu paljud rumalad inimesed, taluda igavust, mida teised rumalad talle tekitasid. Vaimuvaesed inimesed sarnanevad umbrohuga, mis armastab kasvada heas mullas, ja nad vajavad seda enam meelelahutust, et nad ise on igavad.” (Tours'i küree”42.) On ilmselge, et tarviduse korral võiks öelda risti vastupidist ning et pole juhtmõtet, mis karjuks vastupandamatumalt lautréamont'liku pöördmenetluse järele. Olnuks tarvis, tunnustanuks preili Cormon Athanase'i juures omaenese tundepeenusi [délicatesses], sest „suurimad mõtted tulevad südamest”; Birotteau jäänuks rahule oma korteriga, sest „Iollil pole ambitsioonikuseks piisavalt sisu”; 43 talle meeldinuks preili Gamard'i rohmakas salong, sest asinus asinum fricat ${ }^{44}$ jne. Juhtub muide sedagi, et üks ja sama lähteidee annab mõnerealise vahemaa tagant kaks vastandlikku järeldust: „Ja et piiratud mõistusega inimesed kergesti kalduvad kõiksugu tühiasjades tähendusi otsima, hakkas ta äkki pikalt-laialt mõtisklema nende nelja asjaolu puhul, mis igale teisele oleksid märkamata jäänud [---]”; ent: „Ehk küll hilja, märkas vikaar nüüd viimaks seda salajast tagakiusamist, mis talle juba umbes kolme kuu kestel preili Gamard'i poolt osaks sai, kelle kurje kavatsusi mõni arukam inimene oleks taibanud hoopis varem” ${ }^{45}$. Või teisal: „Ja leidlikkusega, mille omandavad preestrid, kes on harjunud juhtima inimeste südametunnistust ja urgitsema pisiasjades pihitoolide sügavuses, hakkas abbé Birotteau kohe..."; ent: „Abbé Biroteau aga [---], kel puudus igasugune ilma- ja elutarkus, kes elas peamiselt missa ja pihitooli vahel, alati tegevuses kõige lihtsamate sisetunde küsimuste lahendamisega, sest ta oli linna kasvatusasutiste ja mõnede teda kõrgelt hindavate kaunishingede pihiisa, - seda

40 IK V, Ik 14. (Artikli autori esiletõsted.) Jälgime siin concatenatio rerum'it [sündmuste käiku (lad k)] Iõpuni, kust leiame suure põhjuse, mis sünnitab väikese tagajärje: „Nii oli siis tema määramise tõenäosus, lootused, mida talle anti proua Listomère'i juures, tema pea nii segi ajanud, et talle meenus külla unustatud vihmavari alles siis, kui ta oma elukoha juurde jõudis."

41 Ilus näide psühhoanalüütilisest eitamisest [dénégation].

42 IK V, Ik 23. (Autori rõhutus.)

43 Autor tsiteerib Louis de Bonald'i ja La Rochefoucauld'd. (Tõlkija märkus.)

44 „Üks eesel hõõrub end vastu teist” (lad k), vrd „üks loll kiidab teist”. (Tõlkija märkus.)

45 IK V, IK 16-17. 
abbé Birotteau'd võis pidada suureks lapseks..."46 Neis pisikestes vastuoksustes, mida Balzac, kui tema tähelepanu oleks nendele juhitud, poleks võtnud vaevaks silumagi hakata, on loomulikult üksjagu hooletust, kuid üksiti paljastavad need lapsused sügavat ambivalentsi, mida narratiivi „loogika” võib kahandada vaid pealiskaudselt. Abbé Troubert'i saadab edu seepärast, et ta otsustab viiekümneaastaselt teesklema hakata, panna inimesi unustama tema auahnust ja „võimekust” ning pidama teda raskelt haigeks kui Sextus Quintust, kuid niisama hästi võiks ta säärase muundumisega Touraine'i vaimulikkonnas umbusaldust äratada (abbé Chapeloud's muide äratabki). Teisalt saadab teda edu ka seetõttu, et kongregatsioon on valinud ta "Touraine'i salajaseks prokonsuliks". Mida on sellise valiku juures silmas peetud? Esiteks „kanooniku positsiooni naiste senati keskel, kes nii osavalt jälgisid provintsi elu"? Teiseks ka tema „isiklikke võimeid”. ${ }^{47}$ Nii siin kui ka mujal võib märgata, et mingi tegelase „võimekus” on kahe teraga mõõk: põhjus ülendamiseks, põhjus ka umbusaldamiseks ja seega kukutamiseks. Niisiis jätab motiivide selline ambivalents autorile täieliku vabaduse - ühes kohustusega epifraasi abil kord üht, kord jälle teist väärtust rõhutada. Nii näiteks on võrdses seisus lollpea ja peen intrigant: autori äranägemise järgi riuklik kas võidab oma riuklikkusele toel („Tours'i küree” õppetund) või langeb omaenese riuklikkuse ohvriks („Vanapiiga” õppetund). Petetud naine võib niihästi kibedusest kätte maksta kui ka armastusest andestada - enam-vähem sääraseid võimalikkusi kordamööda harrastab proua Bargeton „Kaotatud illusioonides”. Et romaanipsühholoogia tasandil võib mis tahes tunne õigustada mis tahes käitumist, on otsused siin peaaegu alati pseudootsused. Ja kõik kulgeb nõnda, nagu oleks Balzac sellest kompromiteerivast vabadusest teadliku ja häirituna püüdnud seda varjata, paljundades peaaegu valimatult kõiki neid motiive, mida seovad sõnad „sellepärast, et”, „sest” või „seega” ning mida tahaks nimetada pseudosubjektiivseteks (nagu Spitzer nimetas „pseudoobjektiivseks” motivatsioone, mida Charles-Louis Philippe oma tegelastele omistas) - motivatsioone, mille kahtlane üliküllus lõppude lõpuks üksnes rõhutab meie jaoks seda, mida need püüdsid maskeerida: narratiivi meelevaldsust [l'arbitraire du récit].

Sellele meeleheitlikule katsele võlgneme me vähemasti ühe rabavaima näite selle kohta, mida võiksime nimetada narratiivi vallutamiseks [invasion] diskursuse poolt. Tõsi, Balzaci puhul on selgitav ja moralistlik diskursus ikka veel enamasti (mis tahes mõnu autor ja ühtlasi lugeja sellest ka saavad) kitsalt narratiivi huvidele allutatud ja tasakaal nende kahe romaanidiskursuse vormi vahel näib olevat enam-vähem alal hoitud. Sellegipoolest - isegi autori lõa otsas, kes on äärmiselt lobahimuline, samas aga ülimalt tähelepanelik dramaatilise hoo suhtes - diskursus laiub, vohab ja paistab sageli äärepealt lämmatavat sündmuste käiku, mida ta oma ülesande poolest peaks valgustama. Seda niivõrd, et narratiivi ülevõim osutub 
selles elutöös, mida ometigi tuntakse „traditsioonilise romaani“ sünonüümina, kui mitte vaidlustatuks, siis vähemasti ähvardatuks. Veel sammuke ja dramaatiline sündmustik nihkub tagaplaanile - narratiiv kaotab oma olulisuse diskursuse kasuks. See on eelmäng romaanižanri lahustumisele ja kirjanduse võidukäigule selle sõna nüüdisaegses tähenduses. Balzacist näiteks Proustini on vähem maad, kui võidakse arvata - Proust, muide, teadis seda paremini kui keegi muu.

\section{[3]}

Naaskem nüüd meie kahe vaidluse juurde tõenäolisuse üle. Keset neid nii iseloomulikke tunnistusi realistlikust illusioonist - kuivõrd vaieldakse ju selle üle, kas toimides nõnda, nagu toimisid Chimène või proua de Clèves, toimisid nad „õigesti” või „valesti”, et tõstatada kaks sajandit hiljem küsimus nende "tegelike” ajendite kohta ${ }^{48}$ - kohtame me kahte teksti, mille käigud ja kavatsused [l'allure et le propos] on sellest hoiakust sootuks kaugel, kuid millele (hoolimata suurtest erinevustest ulatuses ja pikkuses) on ühine omamoodi tervistav kirjanduslik künism. Neist esimene on kümmekonna lehekülje pikkune pamflett nimega "Le Jugement du Cid, composé par un Bourgeois de Paris, Marguillier de sa Paroisse" ${ }^{49}$, mis on omistatud Sorelile ${ }^{50}$. Scudéry esindatavate "teadmameeste” vaatepunkti vastu väidab autor end siin väljendavat „rahva” arvamust, kes vilistab Aristotelesele ja mõõdab näidendite väärtust mõnu järgi, mida need talle pakuvad: „Ma leian, et „Cid” on õige hea tükk [juba] sel ainsal põhjusel, et teenis suure heakskiidu." Sellest pöördumisest publiku otsuse poole saab, nagu teada, klassikaliste autorite ja iseäranis Molière'i teadlik hoiak; see on muide otsustav

48 Sellise suhtumise näiteks kostab Jacques Chardonne: „Seda ülestunnistust kritiseeriti 17. sajandil. See leiti olevat ebainimlik ja eesätt ebatõenäoline. Leidub üksainus seletus: mõtlematus. Kuid selline mõtlematus saab võimalikuks vaid juhul, kui naine oma abikaasat armastab.” Ja ülalpool: „Vaevalt et proua de Clèves [oma abikaasat] armastab. Ta arvab, et armastab. Kuid ta armastab vähem, kui arvab. Ja ometi armastab ta teda rohkem, kui teab end teda armastavat. Need intiimsed ebakindlused loovad keerukuse ja kogu tegelike tunnete käigu." (Tableau de la Littérature française. XVII-XVIII siècles. Pariis, Gallimard, 1939, Ik 128.) Seletus on ahvatlev. Selle ainsaks puuduseks on unustada, et proua de Clèves'i tunded - niihästi oma abikaasa kui ka Nemours'i vastu - ei ole tegelikud, vaid fiktiivsed ja keelelised tunded, teisisõnu tunded, mis ammenduvad nende lausungite koguhulgas, mille kaudu narratiiv neid tähistab. Proua de Clèves'i te gelike (tekstiväliste) tunnete järele pärida on niisama kimäärne kui juurelda, mitu last oli te gelikult leedi Macbethil või kas don Quijote oli päriselt lugenud Cervantest. On muidugi legitiimne otsida sügavamat tähendust teole, mille pani toime proua de Clèves ning mida peetakse apsakaks („mõtlematuseks”), mis viitab mingile hämaramale tegelikkusele; ent sellisel juhul asutakse tahes-tahtmata psühhoanalüüsima mitte proua de Clèves'i, vaid Madame de la Fayette'i või/ja lugejat. Nii näiteks: „Kui proua de Clèves härra de Clèves'ile pihib, tuleb see sellest, et mees on see, keda ta armastab; kuid härra de Clèves ei ole ta mees - ta on tema isa."

49 „Kohus Cidi üle, koostatud ühe Pariisi linnakodaniku, tema kihelkonna vöörmündri poolt” (tõlkija märkus). Gasté, 1898, Ik 230-240.

50 Charles Sorel (?-1674) - hämara elukäiguga, peamiselt pseudonüümide all kirjutanud prantsuse romaanikirjanik. (Tõlkija märkus.) 
argument reeglite vastu, mis väidavad end rajanevat üksnes murel tõhususe pärast. Vähem klassikaline, võiks koguni öelda, et tüüpiliselt barokne, on täpsustus, et „Cidi” veetlus seisneb tema „pentsikuses ja ekstravagantsuses”. See pentsikuse võlu, mida Corneille oma 1660. aastal ilmunud „Examenis” ka kinnitab, meenutades, et too nii teravalt arvustatud Rodrigue visiit Chimène'i juurde pärast krahvi surma põhjustas „vaatajaskonnas teatava kahina, mis andis märku oivalisest uudishimust ja tähelepanu kahekordistumisest", näikse vägagi kindlalt tõestavat, et „vaadetele vastavus” ei ole ainus viis, millega publiku toetust võita - see pole kaugel kogu tõenäolise-teooria hävitamisest või selle sundimisest uutele alustele. Siin aga on peamine idee argumentatsioonis, mille käigus tuleb ilmsiks, et see kaitse ei toimi ilma omamoodi jõhkra vormita sellest, mida nimetame hiljem ja mujal protseduuri paljastamiseks. Sorel ütleb: „Ma tean, et pole sugugi ilmne (= tõenäoline), et tüdruk pidanuks tahtma naituda oma isa mõrtsukaga, kuid see avas võimaluse öelda kauneid teravusi... Ma tean küll, et kuningas toimis vääralt, kui ta don Gormasil oma heaksarvamise järgi tegutseda palumise asemel teda vahistada ei lasknud, kuid vastasel juhul poleks ta ju surnud... Ma tean, et kuningas pidanuks mauride kavatsustest teada saades sadamat kindlustama, kuid kui ta oleks seda teinud, poleks Cid osutanud talle seda suurt teenet, mis sunnib teda talle andestama. Ma tean küll, et Infanta on tarbetu tegelane, kuid ilma temata jäänuks näidendisse tühimik. Ma tean küll, et don Sancho on vilets narr, kuid ta pidi kandma oma mõõka, et Chimène'is hirmu äratada. Ma tean küll, et don Gormasil polnud tarvis oma teenrile rääkida, mida Nõukogus arutati, kuid autor ei osanud teda muust rääkima panna. Ma tean küll, et tegevuspaigaks on kord Palee, kord linnaväljak, kord Chimène'i magamistuba, kord Infanta eluruumid ja kord kuninga omad, ning seda kõike nii segamini, et ühest teise satutakse puhuti võluväel, ühestki uksest läbi minemata. Kuid autoril oli seda kõike tarvis." 51 Vaidluse teravaimas punktis, paar nädalat enne Akadeemia verdikti, mõjus säärane kaitsekõne kui punane rätik härjale. Ent praegu, mil Scudéry, Chapelain ja Richelieu on surnud, "Cid" aga vägagi elus, võime tõdeda, et Soreli sõnad on kuldsed ja väljendavad valjusti seda, mida peaks sisimas mõtlema iga autor: vastus tõenäo-kriitika [critique vérisimiliste] igavesele miks'ile on: sest mul on seda tarvis. Tõenäolisus ja sündsus on väga sageli vaid siivsad viigilehed ning pole paha, kui mõni vöörmünder aeg-ajalt - kirikupinkide väljarentijate suureks meelepahaks - mõningaid „funktsioone” kattest vabastamas käib.

51 Artikli autori esiletõsted. 
„Jugement du Cid" tahtis omal ebadiskreetsel moel olla näidendi kaitsekõne; Valincouri ${ }^{52}$ "Lettres à Madame la Marquise de *** sur le sujet de la Princesse de Clèves" 53 (1679) esindab pigem romaani kriitikat - kriitikat, mis on detailides sageli range, aga mis oma tõsiduses kujutab endast pigem lugupidamisavaldust kui rünnakut. See raamat koosneb kolmest kirjast, millest esimene puudutab ajaloo kulgu ja seda, kuidas sündmused esitatud, teine tegelaste tundeid ja kolmas stiili. Jättes siinkohal välja kolmanda, tuleb esmalt tähele panna, et teine kiri tuleb sageli tagasi esimese juurde ning et tunded pole Valincourile teps mitte kõige tähtsamad. Ja nõnda ei innusta ülestunnistus - Mercure Galantis maha peetud debati peamine aines - teda ainsakski psühholoogiliseks kommentaariks proua de Clèves'i kohta (tähelepanuväärne väljategematus), vaid üksnes kiidulauluks stseeni poolt tekitatud tundeküllasele efektile, millele järgneb kriitika mehe hoiakute suhtes ja meenutus sarnase stseeni kohta ühes Madame de Villedieu' romaanis. Kui Valincour võtab tihti tegelaste käitumise kallal (proua de Clèves'i jultumus, härra de Nemours'i kohmakus ja ebadiskreetsus, härra de Clèves'i tormakus ja läbinägelikkuse puudumine jne), siis arvustab ta seda üksnes niivõrd, kui see mõjutab loo kulgu, mis talle tegelikult huvi pakub. Sarnaselt Soreliga, kuigi vähem ninakalt, asetab Valincour rõhu erinevate episoodide funktsioonile: ülestunnistuse stseeni õigustab see, mida võib nimetada tema vahetuks funktsiooniks (tundeküllasus); samuti uurib Valincour seda stseeni tema pikaajalises funktsioonis, mis on veelgi tähtsam. Sest tundeid, mis on proua de Clèves'il teise mehe vastu (keda ta ei nimeta - siit esimene pikaajaline toime, härra de Clèves'i uudishimu ja juurdlused), ei tunnista ta üksnes oma abikaasale, vaid enese teadmata tunnistab ta neid ka paari sammu kaugusel peidus viibivale Nemours'ile, kes taipab kõike ja tunneb end teatavate detailide järgi ära. ${ }^{54}$ Siit mõjud Nemours'i meeleoludele, mis jäävad pendeldama rõõmu ja ahastuse vahel; siit ka tema pihtimus ühele oma sõbrale, kes räägib kogu loo edasi oma armukesele, kes räägib selle edasi proua troonipärijale, kes räägib selle Nemours'i juuresolekul ([milline] stseen!) edasi proua de Clèves'ile; siit ka printsessi etteheited abikaasale, kelle ta arvab loomulikult olevat ebadiskreetsuse ahela avanud; härra de Clèves'i omapoolsed etteheited naisele - need on mõned ülestunnistuse stseeni pikaajalised toimed, mida eiras ja eirab jätkuvalt enamik lugejaid ${ }^{55}$, keda võlub vaidlus motiivide üle, nõnda et „mis selleni viis?” kaldub

52 Jean-Baptiste-Henri de Valincour (1653-1730) - prantsuse kirjamees, Racine'i ja Boileau lähikondlane. (Tõlkija märkus.)

53 Vt viide 3. (Tõlkija märkus.)

54 „See lõhnab pisut „Astrée järele”, ütleb Fontenelle (Cazes, 1934, Ik 197). Tõsi, kuid asi on selles, et nii „Printsess de Clèves” kui ka [Honoré d’Urfe'i (1567-1625)] „Astrée” on romaanid.

55 Nemours'i olukorra kohta selles ja ühes teiseski episoodis vt siiski: Michel Butor, Répertoire I. Pariis, Minuit, 1960, Ik 74-78 ja Jean Rousset, Forme et Signification. Pariis, Corti, 1962, Ik 26-27. 
panema meid unustama „mida see teeb?". Valincour aga ei unusta. „Ma tean samuti,” ütleb ta Nemours'i pihtimuse kohta, „et see pandi sisse selleks, et valmistada ette kimbatust, millesse proua de Clèves ja härra Nemours hiljem proua troonipärija juures satuvad”; ja veel: „On tõsi, et poleks nad kumbki neid vigu teinud, poleks vahejuhtumit proua troonipärija toas aset leidnud." Ja mida ta neile võtetele ette heidab, on see, et säärased toimed tekitatakse liiga kalli hinnaga ning nii kompromiteeritakse, selle sõna tugevas tähenduses, narratiivi ökonoomsust: „Kas pole ühe seikluse hind liiga kallis, kui selleks hinnaks on vead raamatukangelase mõtetes ja käitumises?” Või teisal: „On ebameeldiv, et seda vahejuhtumit ei võidud sisse tuua teisiti kui tõenäolisuse hinnaga." 56 Näeme, et Valincour on Soreli leebetest pilgetest kaugel: eksimused tõenäolisuse vastu (arukaks peetava naise hooletused, džentelmeni taktitus jne) ei jäta teda ükskõikseks; kuid selle asemel et ebatõenäolisusi nende endi pärast Scudéry või Bussy kombel hukka mõista (mis oleks omane realismi-illusioonile), otsustab ta nende kui narratiivi funktsioonide üle, lähtudes seejuures rentaablussuhtest, mis toimeid võtetega seob, ja mõistes need hukka vaid juhul, kui see suhe kui see suhe on puudulik. Nii et kuigi stseen proua troonipärija pool läheb kalliks maksma, on see iseeneses sedavõrd hea [heureuse], „et rõõm, mille see minus tekitas, pani mind unustama kõik muu," ${ }^{57}$... teisisõnu võtete ebatõenäolisuse - arved on tasa. Mis puudutab seevastu Nemours'i juuresolekut ülestunnistuse hetkel, siis „mulle näib, et tema jaoks ohutuma ja ennekõike loomulikuma (= vähem kuluka) võimaluse tekitamine selleks, et ta võinuks kuulda seda, mida autor tal kuulda lasta soovis, jäi kinni üksnes autori taha". ${ }^{58} \mathrm{Ja}$ veel, printsi surma asjus, mille põhjustas puudulik teave ta nuhilt, kes nägi Nemours'i öösel Coulommiers'i parki sisenevat, kuid ei taibanud näha (või öelda), et see visiit ei toonud kaasa mingeid tagajärgi. Nuhk käitub nagu juhmakas ja ta peremees nagu lollpea ning „ma ei tea, kas polnuks autorist mitte targem pruukida oma kõikvõimu, et teha härra de Clèves'ile ots, kui et anda ta surmale nii vähetõenäoline ettekääne, kui seda on soovimatus kuulata Iõpuni, mida ta teenril talle öelda oli", ${ }^{59}$ - veel üks toime, mis läheb liiga kalliks maksma; on hästi teada, et härra de Clèves peab surema oma naise armastuse pärast Nemours'i vastu, kuid selleks pruugitud ühendus on kohmakas. Narratiivi reegel, mille Valincour vaikimisi välja ütleb, on lihtne ja järsk: eesmärk peab pühitsema abinõu. „Autor pole oma kangelaste käitumise suhtes kuigi nõudlik: ta ei muretse selle pärast, et nad kipuvad end ära unustama, kui sellest aga seiklusi sünnib,” ja veel: „Niipea kui keegi tegelastest [---] ütleb või teeb midagi, mis näib

\footnotetext{
56 Lettres sur le sujet de la Princesse de Clèves. Ed. A. Cazes, 1934, Ik 113-114. (Artikli autori esiletõsted.)

57 Ibid., Ik 115.

58 Ibid., Ik 110.

59 Ibid., Ik 217-218.
} 
meile eksimusena [faute], ei pea me seda nägema nõnda nagu teistes raamatutes, teisisõnu millenagi, mis tuleks teosest eemaldada. Vastupidi: võime olla kindlad, et see on sisse pandud selleks, et valmistada ette mõnd erakordset sündmust." ${ }^{60}$ Autori kaitsmine on felix culpa ${ }^{61}$; kriitiku osaks pole üleastumisi [faute] a priori hukka mõista, vaid püüda leida, millist rõõmu tekitab nende kõrvutamine üksteisega, ja otsustada siis, kas see rõõm vabandab eksimuse välja või mitte. Tõeline patt tema silmis oleks üleastumine ilma rõõmuta, teisisõnu stseen, mis oleks ühtaegu kulukas ja kasutu nagu proua de Clèves'i ja härra Nemours'i kohtumine aias pärast printsi surma: „Kõige kummalisem tundus mulle selle vahejuhtumi puhul tõdemus tema kasutusest. Milleks vaevuda välja mõtlema midagi niivõrd ebaharilikku... vaid selleks, et see nõnda veidral moel Iõpetada? Proua de Clèves'i üksindus katkestatakse, ta juhatatakse kuhugi, kus tal pole kombeks käia; ja kõike seda vaid selleks, et ta võiks oma meelehärmiks härra Nemours'i tagaukse kaudu väljuvat näha."62 Mäng ei vääri küünlaid.

Sedavõrd pragmaatiline kriitika ei rahulda mõistagi vähimalgi määral asjaarmastajaid hingeküsimustes [amateurs d'âme] ning on mõistetav, miks Valincouri raamat kuigi ülistavat vastukaja ei saanud. Südame kaledus, vaimu piiratus, steriilne formalism - säärasel puhul on sellised etteheited vältimatud - ja tähtsusetud. Püüdkem parem sellest kriitikast välja noppida elemendid, mis kuuluvad funktsionaalsesse narratiiviteooriasse, lisaks aga ühte samuti funktsionaalsesse (või ehk tuleks pigem öelda ökonoomilisse) tõenäolise definitsiooni.

[4]

Põhimise antusena tuleb lähtuda sellest juba nimetatud narratiivi meelevaldsusest, mis äratas võlu ja tülgastust Valérys; sellest narratiivi peadpööritavast vabadusest võtta esiteks igal sammul üks või teine siht (vabadus, olles lausunud „Markiis...", jätkata millegi säärasega nagu „väljus” või hoopis „sisenes” või „laulis” või „uinus” jne), seega: suuna meelevald; teiseks: jääda paigale ja laieneda ühe või teise tingimuse, fakti, indeksi või katalüsaatori lisandumise kaudu63 (vabadus esitada pärast „Markiisi” predikaate nagu „de Sévigné” või „kõrk, pikk ja kuivetunud naine” või „tellis oma tõlla ette ja...”) - laiene mise meelevald. „Ehk oleks huvitav kirjutada üks teos, mis näitaks igas oma sõlmpunktis

60 Ibid., Ik 119; 125. (Artikli autori esiletõsted.)

61 Õnnelik eksimus (lad k). (Tõlkija märkus.)

62 Ibid., Ik 129-130.

63 Roland Barthes, Introduction à l'analyse structurale du récit [Sissejuhatus narratiivi strukturaalanalüüsi]. Communications 8, Seuil, Points, 1966, Ik 9. 
paljusust, mis end seal vaimule ilmutada võib ning millest vaim valib välja üheainsa jätku, mis tekstis koha leiab. See tegu asendaks pettekujutluse ainulisest ja tegelikkust jäljendavast kindlaksmääratusest kujutlusega iga-hetk-võimalikust, mis on minu meelest tõele lähemal." 64 Ometi tuleks täheldada, et see vabadus pole õigupoolest lõpmatu ning et iga hetke võimalik allub teatavale hulgale kombinatoorsetele kitsendustele, mis on vägagi võrreldavad nendega, mille surub lausele peale süntaktiline ja semantiline korrektsus: ka narratiivil on omad "grammatilisuse” kriteeriumid, mis kehtestavad näiteks selle, et pärast lausungit [énoncé] „Markiis tellis oma tôlla ette ja...” oodatakse pigem, et „läks väikesele sõidule”, kui et „läks magama”. Ent küllap on metodoloogiliselt mõistlikum käsitleda narratiivi esmalt kui midagi täiesti vaba ning registreerida seejärel selle mitmesugused kindlaksmääratused - kuhjunud kitsendused -, kui et eeldada algusest peale tema „ainulist ja tegelikkust jäljendavat kindlaksmääratust". Järgmiseks tuleks möönda, et seda, mis ilmneb lugejale hulga mehaaniliste kindlaksmääratustena, pole määranud jutustaja. Kirjutanud „meeleheitel markiis...”, pole ta küllap sama vaba jätkama: „...tellis pudeli šampanjat”, kui et „...võttis püstoli ja lasi endale kuuli pähe”. Kuid tegelikkuses asjad nõnda ei käi: kirjutades „markiis...”, teab autor juba, kas ta lõpetab selle stseeni pummelungi või suitsiidiga, ning valib seega keskpaiga Iõppu silmas pidades. Vastupidiselt sellele, mis paistab lugeja vaatepunktist, pole „meeleheitel” see, mis määrab püstoli, vaid hoopis püstol see, mis määrab „meeleheitel”. Naasmaks kanoonilisemate näidete juurde, nentigem, et härra de Clèves ei sure sellepärast, et tema teener käitub juhmakana, vaid et teener käitub juhmakana, selleks et härra de Clèves sureks, või siis, nagu ütleb Valincour, sellepärast, et autor tahab härra Clèves'il surra lasta ning et see fiktsionaalse narratiivi lõplikkus on iga tema elemendi ultima ratio. Tsiteerigem veel viimast korda Valincouri: „Kui autor kirjutab romaani, on see tema jaoks kui väike maailm, mille ta ise loob, ning kõik selle tegelased on tema jaoks kui tema loodud olendid, kelle isand tema täielikult on. Ta võib neile anda hüvesid, vaimu ja vahvust, nii nagu ise soovib, ning lasta neil elada või surra, nii nagu heaks arvab, ilma et ühelgi neist oleks õigus tema toimimise kohta aru nõuda: seda ei või teha isegi lugejad. Teinekord panevad lugejad autorile süüks, et see on lasknud kangelasel surra liiga vara, võimata aimatagi põhjuseid, mis autoril selleks võisid olla; võimata aimata, mis kasu pidi olema sellest surmast 100 edaspidises käigus." ${ }^{65}$ Need tagasivaatelised kindlaksmääratused moodustavad nimelt selle, mida oleme nimetanud narratiivi meelevallaks, teisisõnu, mitte just määramatuse, vaid vahendite määratuse eesmärkide poolt, ehk jämedamalt öeldes: põhjuste määratuse tagajärgede poolt. See fiktsiooni paradoksaalne loogika sunnibki määratlema narratiivi iga elementi, iga ühikut, tema funktsionaalse iseloomu järgi, teisisõnu muu

64 [Paul] Valéry, CEuvres I. Gallimard, Pléiade, 1957, Ik 1467.

65 Valincour, 1925, Ik 216. (Artikli autori esiletõsted.) 
hulgas tema vastastikuse seose järgi mingi muu ühikuga, ${ }^{66}$ ja seletama esimest teise kaudu (vastavalt narratiivi ajalisele järgnevusele) ja nõnda edasi, millest tulenevalt on viimane see, mis valitseb kõiki ülejäänuid ning mida ennast ei valitse miski - seal paikneb meelevalla tuum - vähemasti narratiivi immanentsi seisukohalt, sest sealt edasi on lubatud otsida talle mis tahes psühholoogilisi, ajaloolisi, esteetilisi jne kindlaksmääratusi mujalt. Selle skeemi järgi ripuks kõik „Printsess de Clèves'is” sellest, mis oleks ta pärisomane [proprement] telos: lesestunud proua de Clèves ei naitu härra Nemours'iga, keda ta armastab; nõnda nagu „Bérénice'is" ripub kõik Suetoniuse välja öeldud lahendusest: dimisit invitus invitam ${ }^{67}$.

Skeem, seda küll, ja veel selline, mille taandav toime [l'effet réducteur] on vähem tajutav teose puhul, mille joonis (nagu teada) on ülimalt lineaarne. Ometi ohverdab see skeem möödaminnes selle, mida nimetasime äsja iga episoodi vahetuks funktsiooniks: kuid need funktsioonid on sellele vaatamata funktsioonid ja nende tõeline kindlaksmääratus (mure toime pärast) on sellele vaatamata [nende] eesmärk. Seega leidub narratiivis, isegi kõige unilineaarsemas, funktsionaalset ülekindlaksmääratust, mis on alati võimalik (ja alati ihatav): lisaks pikaajalisele funktsioonile narratiivi käigus hoiab proua de Clèves'i ülestunnistus sedasi koos suurt hulka lühikese ja keskmise pikkusega funktsioone, millest peamisi oleme juba nimetanud. Samuti võib olla olemas narratiivi vorme, mille lõppeesmärk ei lähe täide narratiivi lineaarses käigus, vaid kindlaksmääratuse kimbus: näiteks don Quijote seiklused romaani esimeses osas, mis määravad üksteist vähem, kui on üheskoos määratud (meenutagem siin, et tegelik kindlaksmääratus on vastupidine) kurva kuju rüütli „sõgedusest”, mis hoiab koos funktsioonide kimpu, mille toimed avalduvad narratiivi ajas, jäädes aga loogiliselt ühele ja samale plaanile. Küllap leidub hulk teisigi võimalikke funktsionaalseid skeeme ja leidub ka hajusaid esteetilisi funktsioone, mille rakendumispunkt jääb kõikuvaks ja näiliselt määramatuks. Teose tõele liiga tegemata ei saaks me kindlasti öelda, et „Parma kloostri" 68 telos'eks on see, et Fabrica del Dongo Saccast kahe ljöö kaugusel kloostris sureb, või „Madame Bovary” telos'eks see, et Homais saaks Auleegioni ordeni või au kaotanud Charles Bovary oma lehtlas sureb või koguni... Kõigi Nende nende teoste tegelikule globa al -

66 Vt Roland Barthes, art.cit, Ik 7: „Mis tahes funktsiooni hing on, kui võib nii öelda, tema seeme - see, mis võimaldab tal viljastada narratiivi elemendiga, mis küpseb hiljem."

67 Racine'i tragöödiast pärinev tsitaat „Berenicem invitus invitam Titus dimisit” (Iseenda ja tema kiuste saatis Titus Berenice tagasi) viitab Rooma ajaloolase Suetoniuse kirjeldusele sündmuste kohta, mis leidsid aset pärast tulevase keisri Tituse edukat sõjakäiku Jeruusalemma. Aastal 70 purustasid Rooma väed Teise Templi ning võidukas Titus võttis Rooma kaasa juudi printsessi, kuningas Agrippa I tütre Berenice, kellega tal oli tekkinud armusuhe. Oma võimust hoolimata ei suutnud Titus rahva vastuseisuga toime tulla ja oli sunnitud naise tagasi saatma. (Tõlkija märkus.)

68 Stendhali romaan „La Chartreuse de Parme” (1839), realismi varaseid näiteid. (Tõlkija märkus.) 
sele funktsioonile osutasid Stendhal ja Flaubert ise kaunis täpselt: 69 "Madame Bovary" omaks on olla lillakaspruuni värvi romaan, nagu "Salammbô" on purpurset värvi; „Parma kloostri” globaalseks funktsiooniks on tekitada samu „tundeid” nagu Corregio maalid ja Cimarosa muusika. Sääraste toimete uurimine läheb narratiivi ${ }^{70}$ strukturaalanalüüsi praeguste vahendite pädevusest välja, kuid see asjaolu ei luba veel nende funktsionaalset staatust ignoreerida.

Niisiis oleme siin narratiivi meelevallaks nimetanud tema funktsionaalsuse, mis võib põhjendatult mõjuda halva nimevalikuna; selle funktsionaalsuse raison d'être ${ }^{71}$ on luua kaastähendusena teatavat situatsiooniparallelismi narratiivi ja keele [langue] vahel. Teadupärast ei jää Saussure'i pakutud meelevaldsuse mõiste enam lingvistikaski vaidlustamata. Ent tema kasutuse käigus vääramatuks muutunud vooruseks on vastanduda ühele sümmeetrilisele mõistele, milleks on motivatsioon. Keelemärk on meelevaldne ka selles mõttes, et seda ei õigusta miski muu kui ta funktsioon ning on ju teada, et märgi ja iseäranis „sõna"72 motiveeritus kujutab endast lingvistilises teadvuses tüüpilist realismi-illusiooni kaasust. Motivatsiooni (motivacija) mõiste (nagu funktsiooni omagi) tõid aga õnnelikul kombel moodsasse kirjandusteadusse vene formalistid, osundamaks sellele, kuidas narratiivi elementide funktsionaalsus end põhjusliku kindlaksmääratuse maski taha peidab. Nõnda võib „sisu” [„contenu”] olla pelgalt motivatsioon, teisisõnu aposterioorne õigustus vormile, mis tolle sisu õigupoolest kindlaks määrab: don Quijotet esitatakse õpetatud mehena, et õigustada romaanis sarjavate Iõikude sissetungi, byronlik kangelane on Iõhestatud, et õigustada Byroni poeemide ülesehituse katkelisust jne. ${ }^{73}$ Niisiis on motivatsioon see kausaalne

69 Siiski ei tohiks ajada segamini funktsiooni ja kavatsust: funktsioon võib olla suures osas tahtmatu, kavatsus aga täitumata või siis töö tegelikkuse poolt üle täidetud - Balzaci globaalseks intentsiooniks „Inimlikus komöödias” oli teatavasti võistelda sotsiaalse seisukorraga.

70 Pealegi ei ammendu narratiivse töö narratiivsusega tema olemasolu ega koguni ta kirjanduslikkus. Ükski kirjanduslik narratiiv ei ole üksnes narratiiv.

71 Olemasolu mõte (pr k). (Tõlkija märkus.)

72 Klassikaline näide, millele on viidanud (või mille on leiutanud) Maurice Gramont (Le Vers français: ses moyens d'expression, son harmonie. Pariis, Champion, 1913, Ik 3.): „Ja sõna „laud”? Näete, kui hästi annab see edasi mulje neljale jalale toetuvast siledast tasapinnast."

73 Vt Victor Erlich, Russian Formalism: History - Doctrine. Haag, Mouton, 1955, ptk XI. 
näivus ja alibi, mille annab endale lõpu kindlaksmääratus, mis on fiktsiooni reegliks: ${ }^{74}$ „sellepärast, et”, mis peaks pühkima meelest „milleks'i” - ja seega loomulikustama või realiseerima (tähenduses: laskma paista tegelikuna) fiktsiooni, peites ära selle, mis on temas, nagu ütleb Valincour, ette kooskõlastatud ehk kunstlik: ühesõnaga, fiktiivne. Kindlaksmääratuse ümberpööratus, mis muudab (kunstliku) suhte vahenditelt eesmärgile (loomulikuks) suhteks põhjuselt tagajärjele, teostabki selle realisatsiooni, mida on endastmõistetavalt vaja kirjanduse laiaks tarbeks, mis nõuab, et fiktsiooni võetaks tegelikkuse - olgugi et ebatäiusliku ja poolmängulise - illusioonina.

Narratiivi ökonoomia vaatepunktist kujuneb siin seega diametraalne vastasseis mingi ühiku funktsiooni ja tema motivatsiooni vahel. Kui ühiku funktsioon on (jämedalt öeldes) see, milleks teda tarvitatakse, on ta motivatsioon see, mis tal peab olema, et oma funktsiooni varjata. Teisiti öeldes: funktsioon on kasu, motivatsioon aga hind. ${ }^{75}$ Narratiivse ühiku tootlikkus või, kui soovite, tema väärtus, oleks seega saadav lahutamistehtega: funktsioon miinus motivatsioon. $V=F-M$ on see, mida võiksime nimetada Valincouri teoreemiks. ${ }^{76}$ Ei tohiks liialt naerda selle mõõtesüsteemi üle, mis on küll jämedavõitu, kuid mitte rohkem kui mõni teine, ning annab meile igatahes üsna pasliku tõenäolisuse määratluse, mille pikemast õigustamisest kogu eelnev meid säästab: see on implitsiitne motivatsioon, mis ei maksa midagi. Siin seega $V=F-0$ ehk siis, kui ma õigesti arvutan: $V=F$. Olles kord säärase valemi tõhusust mõõtnud, pole me selle tarvitamisest ega isegi kuritarvitamisest enam üllatunud. Mida ökonoomsemat või rentaablimat võiks veel ette kujutada? Motivatsiooni puudumine, paljas võte, mida formalistid kalliks pidasid? Ent lugejal, kes on olemuselt humanist, kutsumuselt psühholoog, on selles hõrendatud õhus raske hingata; või pigem on tühjusehirm ja tähenduse surve säärased, et see märgi puudumine muutub kiiresti märgiliseks. Siis saab mittemotivatsioon millekski hoopis muuks, kuid just niisama ökonoomseks: nullmotivat-

74 „Alibi tähtsus on muidugi kõikuv. Oma tähtsuse tipul tundub ta olevat realistlikus romaanis 19. sajandi Iõpul. Varasematel perioodidel (näiteks antiikajal või keskajal) ei püüa narratiivi konarlikum või aristokraatlikum olek oma funktsioone põrmugi varjata: „Odüsseia” ei sisalda ainsatki üllatust; kõik öeldakse ette ära; ja kõik, mis öeldakse, ka juhtub [---]. See kindlustunne ennustatud sündmuste täidemineku osas puudutab sügavalt intriigi mõistet [---]. Mida ühist on meile harjumuspärasel kausaalsel intriigil „Odüsseiale” omase ettemääratud intriigiga?" (Tzvetan Todorov, Le Récit primitif. Tel Quel, no. 30, 1967, Ik 55.)

75 Narratiivsuse kõrval tuleb siiski arvesse võtta motiveeriva diskursuse võimalikku vahetut funktsiooni. Narratiivse mehaanika seisukohalt võib mingi motivatsioon olla kulukas [onéreuse], mõnel muul, näiteks esteetilisel tasandil aga vägagi tasuv: võtkem näiteks mõnu, olgu see kahtlane [ambigu] või mitte, mida pakub Balzaci lugejale balzaclik diskursus - ja mis võib vabalt minna nii kaugele, et narratiivse vaatepunkti täielikult kõrvaldab. Ja mitte ajaloo pärast ei loe me Saint-Simoni või Michelet'd.

76 Siin oleks paras aeg meenutada, et mõned silmapaistvad õpetlased ei omista „Kirju Printsess de Clèves'i asjus" mitte Valincourile, vaid hoopis P. Bouhours'ile. [Artikli autori märkus.]

Père Bouhours - 17. sajandi jesuiidist kriitik. (Tõlkija märkus). 
sio oniks. Nii sünnib uus tõenäolisus ${ }^{77}$, mis on meie oma, tõenäolsus, mida oleme hiljaaegu kummardanud ning mis meil tuleb samuti põletada: motivatsiooni puudumine kui motivatsioon.

Sõnastagem nüüd ülevaatlikult selle essee veidi ülekoormatud väited [propos].

1. Olgu eristatud kolm narratiivi tüüpi:

a) tõenäoline ehk implitsiitse motivatsiooniga narratiiv, näiteks: „Markiis tellis oma tõlla ette ja läks väikesele sõidule";

b) motiveeritud narratiiv, näiteks: „Markiis tellis oma tõlla ette ja läks magama, sest ta oli kole kapriisne" (esimese järgu ehk kitsendatud motivatsioon) või näiteks: „....sest, nagu markiisid ikka, oli ta kole kapriisne" (teise järgu ehk üldistav motivatsioon);

c) meelevaldne narratiiv, näiteks: „Markiis tellis oma tõlla ette ja läks magama.”

2. Olgu seejärel märgitud, et formaalselt ei erine a-tüüp c-tüübist mitte millegi poolest. Erinevus „meelevaldse” ja „tõenäolise” narratiivi vahel sõltub põhimiselt vaid psühholoogilist või muud laadi otsusest, mis on tekstiväline ja ülimalt muutlik: ajast ja kohast sõltuvalt võib iga „meelevaldne” narratiiv saada „tõenäoliseks” ja vastupidi. Seega on eristus asjakohane üksnes motiveeritud ja mittemotiveeritud narratiivide vahel („meelevaldne” või „tõenäoline”). See eristus juhatab meid ilmselgelt tagasi juba eespool78 ära märgitud vastanduse juurde narratiivi ja diskursuse vahel.

Prantsuse keelest tõlkinud Anti Saar

77 Kui nõustume, et tõenäolist iseloomustab $M=0$. Meenutagem neile, kellele säärane ökonoomiline väljendus tundub kohatu, et (muu hulgas) matemaatikas määrab ökonoomsus elegantsi.

78 Sama autori artiklis „Frontières du récit” („Narratiivi piirid”), Figures II. Pariis, Éditions du Seuil 1969, Ik 49-69). (Tõlkija märkus.) 